\title{
Autonomia Escrava na Formação do Estado Nacional brasileiro: o caso do morar sobre si no Rio de Janeiro
}

Slave Autonomy during the Formation of the Brazilian NationState: the Issue of Living Apart from the Masters in Rio de Janeiro

Ynaê Lopes dos Santos

Mestre em História pela Universidade de São Paulo

\section{Resumo}

A maior mobilidade escrava, caracteristica dos grandes centros urbanos, permitiu que o alargamento da autonomia cativa também se expressasse por meio da atividade do morar, criando a prática do escravo morar sobre si, prática na qual os escravos não habitavam a casa de seus senhores. 0 presente trabalho pretende examinar as formas pelas quais o Estado nacional brasileiro lidou com essa prática no Rio de Janeiro, a fim de entender até que ponto ele pode legislar sobre a autonomia escrava.

\section{Abstract}

The larger slave mobility that characterized great urban centers, allowed the widening slave autonomy to manifest also through living arrangements, creating to the slave the practice of living by himself. According to this practice the slaves did not have to live in the master's house. The present paper intends to examine the ways in which the Brazilian Nation-State dealt with this practice in Rio de Janeiro, in order to understand up to what point the State legislated over slave autonomy.

\section{Palavras-chave}

escravidão, resistência, Corte imperial, Império do Brasil, história social

\section{Keywords}

slavery, resistance, Imperial Court, Brazilian Empire, social history 
Arquivo Geral da Cidade do Rio de Janeiro. Códice 6.1.56, p. 132

2

Arquivo Geral da Cidade do Rio de Janeiro. Código de Posturas de 1838.

Um importante trabalho que tomou a escravidão urbana como anomalia do sistema escravista foi: PRADO Jr, Caio. Formação do Brasil Contemporâneo. (24a. reimpressão). São Paulo: Brasiliense, 1996. p. 223.

Para compreender com mais detalhes a atividade do ganho e a diferença com a escravidão de aluguel, ver: ALGRANTI, Leila Mezan. 0 Feitor Ausente. Estudo sobre a escravidão urbana no Rio de Janeiro 1808-1821. Petrópolis: Editora Vozes, 1988. p.70; SILVA, Marilene Rosa Nogueira. O Negro na Rua. A nova face da escravidão. São Paulo: Hucitec, 1988. p. 87-89; SOARES, Luiz Carlos. Os escravos de ganho no Rio de Janeiro do século XIX. In: Escravidão Revista Brasileira de História, vol. 16, São Paulo: Marco Zero ANPUH, 1988. p. 107-142.
No ano de 1868, José Francisco dos Santos, morador da freguesia de São João do Meriti, encaminhou-se à Câmara Municipal do Rio de Janeiro a fim de solicitar licença para que seu escravo, Amiceto Crioulo, saisse ao ganho pelas ruas da cidade. ${ }^{1}$ Segundo a postura municipal aprovada em 1838 - que previa que todo escravo, liberto ou livre que trabalhasse nas ruas cariocas deveria ter licença concedida pela Câmara Municipal ${ }^{2}-$, o requerente seguiu o procedimento protocolar vigente. Mediante o pagamento de cem mil réis, José Francisco conseguiu que seu escravo Amiceto obtivesse permissão para sair ao ganho, licença que deveria ser renovada anualmente.

Contudo, o pedido feito por José Francisco tinha um detalhe que o diferenciava dos demais: senhor e escravo não moravam na mesa residência. Enquanto José Francisco residia na freguesia de São João de Meriti (região rural da província do Rio), seu cativo habitava uma das vias mais movimentadas da Corte imperial, a Rua do Ouvidor. A singularidade desse documento aponta para a prática recorrente no Rio de Janeiro oitocentista: a possibilidade do escravo morar sobre si, habitando outras casas que não a de seus proprietários.

A autonomia escrava no espaço urbano, que permitiu que cativos morassem longe de seus amos foi vista, durante muito tempo, como uma espécie de anomalia da instituição escravista. ${ }^{3}$ Em primeiro lugar, porque as próprias cidades eram tidas como espaços de menor importância na análise do sistema colonial, tendo em vista o caráter predominantemente agrícola e monocultor da América Portuguesa. Em segundo, a maior mobilidade desfrutada pelos escravos nas ruas dos grandes centros urbanos, a atividade do ganho e o significativo número de alforrias obtidas nesses espaços pareciam nuançar a violência inerente ao cativeiro, o que tornava a escravidão urbana uma subcategoria no âmbito do sistema escravista.

No entanto, trabalhos historiográficos mais recentes mostram que não foi isso que aconteceu. Mais do que adaptar-se, a escravidão fez parte do cotidiano, das leis e das práticas que permearam a vida nas cidades. 0 presente trabalho pretende analisar, justamente, as formas pelas quais essa adaptação se deu, buscando compreender como o Estado brasileiro nascente encarou a problemática da autonomia escrava naquela que foi a maior cidade escravista das Américas.

\section{Escravidão Urbana no Rio de Janeiro}

A forte presença escrava no mundo urbano deveu-se à possibilidade deles serem alugados ou colocados ao ganho. No aluguel, também comum nas regiões rurais, o cativo era emprestado por tempo determinado e mediante pagamento de um senhor para outro, podendo realizar variada gama de atividades. Já no caso do ganho - característico dos grandes centros urbanos do Brasil, como Salvador, Recife e a capital da Corte -, o escravo teria que dispor de sua força de trabalho, passando a maior parte do tempo nas ruas à procura de serviços e, portanto, longe das vistas de seu senhor. ${ }^{4}$

Devido à mobilidade inerente ao ganho, o escravo era, muitas vezes, responsável pelo seu próprio sustento. Portanto, o proprietário ficava isento das preocupações freqüentes nos plantéis escravistas, referentes à sobrevivência de seus trabalhadores - alimentação, vestuário, doenças, etc. Além disso, o cativo deveria entregar semanalmente, ao seu senhor, a quantia previamente estipulada por ele, não importando os meios pelos quais esse dinheiro seria obtido. Tendo em vista as vantagens que os senhores conseguiriam ao colocar seus cativos no ganho, não é de estranhar que as ruas 
LIMA, Oliveira. D. João VI no Brasil (3a edição) Rio de Janeiro: TOPBOOKS, 1996. p. 593.

SANTOS, Ynaê Lopes dos. Além da Senzala. Arranjos escravos de moradia no Rio de Janeiro (1808-1850). 2007. 171f. Dissertação (mestrado em História Social). Faculdade de Filosofia, Letras e Ciências Humanas, Universidade de São Paulo, São Paulo, 2007.

7

Vale dizer que o não cumprimento de acordos feitos com seus senhores não foi a única nem a principal razão da fuga escrava. A violência, característica de toda sociedade escravista, a concorrência por trabalho nas ruas cariocas e a luta pela liberdade foram outros tantos motivos que levaram escravos de todo o Brasil a fugir. Importante ressaltar que nos últimos anos a fuga escrava tem sido tema de pesquisas e debates historiográficos. Um dos primeiros trabalhos que abordam as diversas "modalidades" de fuga escrava foi: REIS, João José; SILVA, Eduardo. Negociação e Conflito. A resistência negra no Brasil escravista. São Paulo: Cia. das Letras, 1989. p. 62-78.

HOLLOWAY, Thomas. Polícia no Rio de Janeiro. Repressão e resistência numa cidade do sécuIo XIX. Rio de Janeiro: Fundação Getúlio Vargas Editora, 1997. p. 63-64.

\section{9}

Apesar da inexistência de um código específico para a escravidão, no periodo colonial inúmeras leis referentes aos escravos foram produzidas. Ver: LARA, Silvia Hunold. Legislação sobre escravos africanos na América portuguesa. Nuevas Aportaciones a la Historia Jurídica de lberoamerica. Madri: Fundación Histórica Tavera-Digibis-Fundación Hernando de Laramendi, 2000 (Cd-Rom). cariocas fossem apinhadas de negros (escravos, libertos ou nascidos livres), realizando as mais diferentes atividades, que, nas palavras de Oliveira Lima, "(...) emprestavam à capital do Reino Unido de Portugal, Brasil e Algarves o seu aspecto estranho e único na monarquia, compartilhado é claro pelas outras cidades do litoral brasileiro" 5.

A possibilidade do escravo morar longe de seu amo foi uma das facetas da estranheza descrita por Oliveira Lima. Essa prática não só permitiu que diversos cativos conseguissem reconstruir seus laços de solidariedade e afeto em espaços próprios - que poderiam ser quartos alugados, casebres, cortiços, etc. -, como facilitou o trânsito deles pelo Rio de Janeiro, principalmente na região portuária e comercial da cidade. Entretanto, esse maior trânsito também trouxe problemas, sobretudo para as autoridades que deveriam garantir a segurança e o bem estar da cidade. Como controlar escravos que podiam morar onde melhor thes aprouvesse?

Durante o período joanino, diversos casos apontaram os sucessos dos escravos em negociar espaços autônomos de moradia com seus proprietários. ${ }^{6}$ De maneira geral, essa diversidade era fruto da relação que os cativos estabeleciam com seus proprietários. Ainda que as residências senhoriais reservassem um espaço à sua escravaria, por menor que fosse, muitos cativos conseguiram acordar com seus amos a possibilidade de habitarem outros locais. Quando não se chegava a um consenso, alguns escravos apelavam para fugas temporárias ou até mesmo permanentes. ${ }^{7}$ Nesses casos, o Estado, via Intendência de Polícia, era acionado a fim de devolver os cativos para seus respectivos senhores e prevenir possiveis ajuntamentos ou formação de quilombos.

Feliz ou infelizmente, é justamente a partir do momento no qual o Estado entra em cena que se torna possivel vislumbrar algo sobre a moradia cativa autônoma. E mesmo assim, com raras exceções, tratam-se de situações que precisam ser lidas nas entrelinhas da documentação policial, já que a materialidade da vida escrava era assunto decidido na privacidade da relação entre senhor e seu cativo. Todavia, é importante salientar que, em nenhuma das situações examinadas, o Estado joanino atravessou esses acordos privados. Conforme Holloway apontou, esse Estado dividiu com os proprietários as responsabilidades em relação aos escravos do Rio: os senhores eram responsáveis pelos aspectos materiais da vida cativa cabendo ao Estado cuidar da sua circulação nas ruas da cidade. ${ }^{8}$

\section{Autonomia escrava na Formação do Estado nacional brasileiro}

A inexistência de um "código negro" para o Brasil colonial ou para o periodo em que foi elevado a Reino Unido de Portugal e Algarves (1815) reforça os limites de atuação do Estado no que tange o governo sobre os escravos $^{9}$, embora essa atuação fosse mais constante - e porque não dizer cotidiana - nas grandes cidades. Porém, a partir de setembro de 1822, inicia-se a formação de um novo Estado nacional, que se pretendia soberano, independente e liberal, mas que, sobretudo, moldou a escravidão à sua constituição, adaptando os significados da palavra liberdade de acordo com seus interesses. A aparente contradição entre a independência política e a manutenção do escravismo num contexto de profundas mudanças sóciopolíticas no quadro Atlântico aponta a necessidade em entender que Estado era esse e, principalmente, as formas pelas quais os assuntos relacionados à escravidão foram tratados. Terá ele respeitado os mesmos limites vistos até aqui, ou a manutenção da escravidão em uma nação que se forjava necessitava de outras formas de atuação estatal? 
10

Arquivo Nacional. Termos de Bem Viver. Coleção Polícia da Corte. Códice 410, vol. 2, p.247, 03/08/1823
11

Importante lembrar que Debret foi um dos viajantes que vivenciou a independência do Brasil, fato que não parece ter mudado suas observações sobre os diferentes aspectos da escravidão urbana que analisou.

12

Durante muitos anos, a historiografia brasileira acreditou que os eventos de 1822 não foram significativos na História do Brasil, haja vista o incremento do uso da mão-de-obra escrava e a manutenção de uma economia baseada na exportação de gêneros tropicais. Cf. PRAD0 Jr., Caio. Formação do Brasil Contemporâneo, (24. reimpressão). São Paulo: Brasiliense, 1996. Um trabalho recente que traz um ótimo balanço dos estudos historiográficos sobre a independência do Brasil é: COSTA, Wilma Peres. A Independência na Historiografia Brasileira. In: JANCSO, I. (org.). Independência: História e Historiografia. São Paulo: Hucitec e Fapesp, 2005. p. 53- 118

\section{3}

JANCSÓ, István; PIMENTA, João Paulo Garrido. "Peças de um mosaico (ou apontamentos para o estudo da emergência da identidade naciona brasileira)". In: MOTTA, Carlos Guilherme. (org.). Viagem Incompleta. A experiência brasileira (1500-2000). Formação:História. São Paulo: SENAC, 2000. p. 127-176

14

Ibidem, p.130-132.
Em outubro de 1823, Jacinto Gomes e Domingos Pereira compareceram à Secretaria da Intendência a fim de assinarem termo de não mais darem coito a escravos. 10 Nesse caso, o Estado, via Intendência de Polícia, tentava proibir que os cativos exercessem a prática do morar sobre si sem a anuência senhorial; para tanto, a Intendência advertia que aqueles que ajudavam os cativos em suas "pequenas fugas" ficavam sob a ameaça da prisão. Situações parecidas foram encontradas na documentação que trata do período joanino. Tal semelhança aponta que, aparentemente, a Independência do Brasil não trouxe nenhuma mudança substancial no que diz respeito aos arranjos autônomos de moradia escrava no Rio de Janeiro: muitos escravos continuaram recebendo coito de livres e libertos contra a vontade de seus senhores, dando novos significados à prática do morar.

No que tange à escravidão doméstica, a semelhança existente entre os relatos dos viajantes que visitaram o Rio no período joanino com aqueles que estiveram depois da independência, sugere o mesmo: de maneira geral, as residências dos segmentos médio e alto da sociedade tinham espaços reservados à sua escravaria. ${ }^{11} \mathrm{Na}$ realidade, a independência do Brasil e o processo de formação do Estado nacional parecem não ter modificado os condicionantes básicos do governo dos escravos nos espaços urbanos, quer nas ruas e praças da cidade, quer nas casas senhoriais.

Contudo, essa permanência não foi resultado de um laissez-aller da politica brasileira após 1822 , conforme se acreditou durante alguns anos. ${ }^{12}$ De acordo com as considerações de István Jancsó e João Paulo Pimenta, a identidade nacional brasileira e o próprio Império do Brasil iniciaram sua formação por meio da construção de um Estado que manteve a escravidão sob controle. ${ }^{13}$ De acordo com os dois autores, a América Portuguesa era um verdadeiro amálgama de diversas pátrias, entendidas como locais de origem, espalhadas em um país (o Brasil) e unidas por única nação (a portuguesa). Essas pequenas pátrias, com identidades politicas plurais, estabeleceram diferentes relações com a metrópole, traçaram caminhos diversos e, por isso, tinham expectativas próprias do Estado que desejavam. ${ }^{14}$ Parafraseando Jancsó e Pimenta, a escravidão foi uma espécie de cimento para a junção das peças desse mosaico que deu à formação do Brasil seu caráter singular.

Diferentemente do que ocorreu no restante do continente americano, o Brasil transformou-se em uma monarquia parlamentar fortemente assentada na instituição escravista. Para além das diferenças internas existentes desde a época colonial, o início do século XIX foi decisivo para aquilo que, no final da década de 1840, seria de fato o Império do Brasil. Em meio às convulsões da Era das Revoluções, em 1808, a Corte portuguesa rumou às pressas para sua principal colônia com o objetivo de assegurar sua soberania nacional ameaçada pela invasão napoleônica. Tal atitude acarretou numa série de mudanças, principalmente na cidade do Rio de Janeiro que, como foi explicitado, tornouse a nova sede de poder do Império lusitano.

Segundo Maria Odila Leite da Silva Dias, a transferência da Corte lusa trouxe não só novos capitais - com a abertura dos portos para as nações aliadas e a migração de significativo número de comerciantes portugueses e europeus -, como o enraizamento do Estado português associado aos interesses das camadas dirigentes da região centro-sul do Brasil. Tomando como base a antiga prática da participação de burocratas nascidos no Brasil na administração pública portuguesa, Dom Rodrigo de Souza Coutinho e o Conde da Bragança foram tão eficientes em transformar o Rio em uma Lisboa minituarizada, que, para muitas capitanias, foi praticamente a mesma coisa 
DIAS, Maria Odila Leite da Silva. A Interiorização da Metrópole. In: A Interiorização da metrópole e outros estudos. São Paulo: Alameda, 2005. p. 32-33.

\section{6}

MATTOS, Ilmar R. Construtores e Herdeiros. A trama dos interesses na construção da unidade política. Revista Almanack Brasiliense, São Paulo, n.1, p.8-26. maio de 2005. (www.almanack.usp.br).

\section{7}

LOBO, Maria Eulália Lahmeyer. História do Rio de Janeiro (do capital comercial ao capital industrial e financeiro) vol. 1. Rio de Janeiro: IBEMEC, 1978.

\section{8}

Para Emília Viotti da Costa, a anulação dos monopólios e a liberalização da economia no Brasil produziram um significativo descontentamento de Portugal, que olhava com saudosismo os ditames do pacto colonial. Cf. COSTA, Emilia Viotti da. Introdução ao estudo da Emancipação política do Brasil. In: Da Monarquia à República Momentos Decisivos. (5a. Edição). São Paulo: Brasiliense, 1987. p. 35-37.

\section{9}

Nos últimos anos, a experiência constitucional portuguesa em meio à Era das Revoluções tem recebido estudos cuidadosos como o trabalho de ALEXANDRE, Valentim. Os Sentidos do Império - questão colonial na crise do Antigo Regime português. Porto: Afrontamento, 1993. No caso da participação de deputados brasileiros, ver: BERBEL, Márcia Regina. A Nação como Artefato. São Paulo: Hucitec/Fapesp, 1999.

\section{0}

Cf. BERBEL, Márcia Regina; MARQUESE, Rafael de Bivar. A escravidão nas experiências constitucionais ibéricas 1810-1824. Texto apresentado no Seminário Internacional Brasil: de um Império a outro (1750-1850). São Paulo, setembro de 2005. Artigo disponivel no site: www. estadonacional.usp.br

21

Ibidem, p. 24. tratar com os dois centros de poder. ${ }^{15}$ Tal processo, chamado pela autora de interiorização da metrópole, resultou na centralidade política da cidade do Rio de Janeiro, que acabou exercendo dois papeis contraditórios: ao mesmo tempo em que era a cabeça da Monarquia, foi responsável pela negação do Império luso. ${ }^{16} \mathrm{~A}$ independência ocorreu, justamente, quando os interesses da elite ilustrada brasileira entraram em descompasso com a política pregada pelos portugueses, principalmente diante a ameaça de um possivel retorno da Corte e de todo o aparelho estatal para o velho continente, o que, em última instância, representaria a volta de práticas políticas do Antigo Regime.

Era inegável que, desde 1808, as transações econômicas haviam favorecido os negociantes da região sudeste, expressando-se inclusive nas alianças adotadas entre políticos e homens de grosso trato. Dados trabalhados por Maria Eulália Lobo mostraram a crescente exportação dos produtos brasileiros e o aumento da comercialização com outras regiões do mundo. ${ }^{17}$ Importante lembrar que o próprio tráfico transatlântico de escravos avolumou-se ainda mais, contando para isso com o suporte do governo joanino, mesmo face às pressões inglesas para a supressão desse comércio.

De fato e de direito, o Rio de Janeiro tornou-se a capital do Império português, causando não só a insatisfação daqueles que ficaram na pátria mãe 18 , como certa contradição na governabilidade deste império ultramarino, já que havia uma distância cada vez maior entre a cidade e as demais localidades coloniais. Em parte esse problema foi resolvido por meio da elevação do Brasil a Reino Unido de Portugal e Algarves em 1815. Mas essa medida não foi suficiente para sanar as contradições de uma colônia-Corte. Além disso, a queda de Napoleão foi a gota d'água para os portugueses exigirem o retorno de D. João VI, fato que desembocou na Revolução do Porto em 1820. Em janeiro do ano seguinte, reuniram-se as Cortes Constituintes da Nação Portuguesa marcando o retorno "reinventado" da experiência constitucional no pais.

A complexidade que marcou as Cortes Constituintes, as discussões acerca das possiveis heranças das experiências constitucionais vividas na crise do Antigo Regime e o próprio desenrolar dos acontecimentos entre janeiro de 1821 e setembro de 1822 apontam que esse é um assunto que demanda detalhada análise histórica. ${ }^{19}$ No que concerne esse trabalho, dois pontos merecem especial atenção: a participação dos deputados brasileiros e os debates acerca do cativeiro.

Ao analisarem a escravidão nas experiências constitucionais ibéricas, Rafael Marquese e Márcia Berbel deixaram claro como a presença dos deputados brasileiros foi decisiva nas discussões sobre a instituição. $20 \mathrm{~A}$ despeito da forte influência da Corte de Cádis (1811-1812), no caso de Lisboa a escravidão foi tema debatido. Após o momento inicial de expectativa em relação ao retorno de D. João VI e a ofensiva para eleger os deputados na América (primeiro semestre de 1821), pernambucanos e depois baianos chegaram a Lisboa, em 1821, reivindicando maior autonomia das províncias. Segundo Berbel e Marquese, poucas semanas antes, a escravidão havia sido discutida pelo congresso. Entretanto, foi apenas a partir de fevereiro de 1822, quando D. Pedro I tinha decidido ficar no Brasil - à revelia do desejo de muitos políticos de Portugal - que o debate sobre o cativeiro na América foi retomado. Nessa data, os deputados paulistas recém chegados em Portugal traziam uma plataforma que previa a defesa da unidade do Reino do Brasil ratificando a presença do príncipe Regente nesse lado do Atlântico. ${ }^{21}$ 
Para entender o que foi a experiência constitucional de Cádis ver: BERBEL, Márcia Regina; MARQUESE, Rafael de Bivar. A escravidão nas experiências constitucionais ibéricas 1810-1824 Texto apresentado no Seminário Internacional Brasil: de um Império a outro (1750-1850). São Paulo, setembro de 2005. Artigo disponivel no site: www.estadonacional.usp.br, p. 5-19.

23

Ibidem, p. 26.

24

Ibidem, p. 27.

\section{5}

As discordâncias políticas entre brasileiros e portugueses não foram os únicos motivos para a proclamação da independência. Jancsó e Pimenta afirmam que nas primeiras décadas do oitocentos, o conceito de nação, mesmo que fluido, já de espalhava pelo mundo atlântico. A América Portuguesa já havia vivido experiências revolucionárias nas quais o gérmen nacionalista fazia parte das reivindicações, ainda que de forma difusa. Cf. JANCSÓ, István; PIMENTA, João Paulo Garrido. "Peças de um mosaico (ou apontamentos para o estudo da emergência da identidade nacional brasileira)". In: MOTTA, Carlos Guilherme. (org.). Viagem Incompleta. A experiência brasileira (1500-2000). Formação: História. São Paulo: SENAC, 2000. p. 159-160.

\section{6}

Nos últimos momentos das Cortes Constituintes os estremecimentos foram tamanhos que alguns deputados brasileiros se recusaram a jurar a Constituição e sete fugiram para Inglaterra onde escreveram e publicaram o manifesto de Falmouth, no qual o porquê das diferenças com as Cortes portuguesas era explicitado. Cf. BERBEL, Márcia Regina; MARQUESE, Rafael de Bivar. Op. Cit. p. 28-30.

\section{7}

MATTOS, Ilmar R. Construtores e Herdeiros. A trama dos interesses na construção da unidade política. Revista Almanack Brasiliense, São Paulo, N.1, p. 16, maio de 2005. (www.almanack.usp.br).

\section{8}

Ibidem, p.17.
Assim como ocorrido em Cádis (1810-1814), nas Cortes portuguesas, os parlamentares dos dois lados do oceano adotaram a estratégia de silenciar o debate sobre escravidão e o tráfico negreiro na constituição, ainda que a manutenção de ambos fosse ponto passivo. ${ }^{22}$ Berbel e Marquese salientam que propostas como de Borges de Barros, que previa a substituição gradual da mão-de-obra cativa por imigrantes europeus, não foram discutidas uma única vez. ${ }^{23}$ Contudo, esse silêncio não permaneceu quando o assunto foi o procedimento eleitoral. Retomando os artigos 22 e 29 da Constituição espanhola, o deputado português Miranda propôs que libertos e seus descendentes fossem proibidos de votar. ${ }^{24} \mathrm{~A}$ partir de então, as singularidades que caracterizaram as diversas pátrias existentes no Brasil se submeteram à defesa de um interesse comum. Deputados baianos, pernambucanos, fluminenses, paraenses e paulistas defenderam, em uníssono, a concessão do direito à cidadania para forros e seus filhos, defesa que foi acatada pelos demais deputados. A proximidade desses parlamentares ficou maior quando, em maio de 1822, as Cortes decidiram enviar tropas para a Bahia com o intuito de prevenir uma reedição da rebelião de São Domingos, além de combater do ideal de independência que se disseminava. Conhecedores de suas pátrias e de seu país, os deputados brasileiros contra-argumentaram que a demografia brasileira não viabilizaria um levante escravo de tamanha proporção haja vista o significativo número de libertos de compunham a população.

Desse modo, as pluralidades que compunham o Brasil se uniram na defesa do que viria a ser um dos princípios organizadores do Estado brasileiro: a escravidão. Mas não qualquer escravidão. Para além do trabalho compulsório e da manutenção do tráfico negreiro, os deputados do Reino Unido de Portugal, Brasil e Algarves lutavam pela legitimação da forma - difundida, enraizada e eficaz - de governar os escravos, não admitindo interferências externas.

À medida que parlamentares brasileiros identificavam interesses em comum, a distância em relação aos portugueses aumentava, indicando a dificuldade de uma reconciliação entre as duas partes do Atlântico. Antes mesmo do juramento da Constituição da Nação Portuguesa, o Brasil já havia proclamado sua independência 25 e convocado uma Assembléia Constituinte no Rio de Janeiro, que retomaria parte das discussões realizadas em Lisboa, só que agora com o objetivo de construir um Estado independente. ${ }^{26}$

As agitações que marcaram o periodo pré-independência não acabaram após setembro de 1822. Nessa altura, conflagrou-se uma dupla tentativa de expansão do território brasileiro. De um lado, a inventiva sobre as regiões do Prata e as possessões de Angola, ambas, no entanto fracassadas. De outro, a expansão interna que, segundo Ilmar Mattos "objetivava ligar aquelas províncias a um projeto gestado no Rio de Janeiro, de modo que compartilhasse uma identidade politica diversa - brasileira" 27 . Ainda que demorada e conflituosa, tal expansão foi vitoriosa.

0 projeto político citado por llmar Mattos teve suas bases calcadas na carta Constitucional brasileira, outorgada em 1824 por D. Pedro I. Fortemente influenciada pelas discussões e tomadas de posição dos deputados brasileiros nas Cortes Constituintes em Lisboa e pela Assembléia Constituinte do Rio de Janeiro de 1823, a Constituição do Estado nacional brasileiro se assentava por meio de um pacto social que reiterava as desigualdades existentes no pais que se forjava. 28 
29

ALENCASTRO, Luiz Felipe de. A Vida Privada e a Ordem Privada no Império. In: História da Vida Privada no Brasil. Império: a corte e a modernidade nacional. Vol. 2. São Paulo: Cia. das Letras, 2004. p.17.

\section{0}

Berbel e Marquese lembram que tal diferenciação foi elaborada na Assembléia Constituinte de 1823, sendo reutilizada no ano seguinte. $\mathrm{Cf}$. . BERBEL, Márcia Regina; MARQUESE, Rafael de Bivar. A escravidão nas experiências constitucionais ibéricas 1810-1824. Texto apresentado no Seminário Internacional Brasil: de um Império a outro (1750-1850). São Paulo, setembro de 2005. Artigo disponivel no site: www.estadonacional.usp.br, p. 30-32.

31

Ibidem.

32

Importante lembrar que em sociedades escravistas como a América Portuguesa e o Brasil imperial, a liberdade se expressava, muitas vezes, não só pela compra ou a obtenção da alforria, mas também ao tornar-se senhor de escravos. E isso estava claro para os homens que pensaram a formação do Estado nacional brasileiro. No Brasil, a alforria constituiu-se como uma espécie de válvula de escape do sistema escravista. Cf. FlORENTINO, Manolo. Sobre minas, crioulos e a liberdade costumeira no Rio de Janeiro, 1789-1871. In: (org). Tráfico,

Cativeiro e Liberdade. Rio de Janeiro, séculos XVII-XIX. Rio de Janeiro: Civilização Brasileira, 2005; PATTERSON, Orlando. Slavery and Social Death: a comparative study. Cambridge, Havard University Press, 1982; MARQUESE, Rafael B. Resistência, tráfico negreiro e alforrias, séculos XVII e XIX. Novos Estudos CEBRAP, São Paulo, 74: p. 107-123. março de 2006.

33

Nesse artigo, o autor também demonstrou, por meio do exame de textos prescritivos, que o Estado deveria ficar isento das responsabilidades sobre os cativos, a não ser que a propriedade e a nação fossem ameaçadas. Cf. MARQUESE, Rafael de Bivar. Governo dos escravos e ordem nacional: Brasil e Estados Unidos, 1820-1860. In: JANCSÓ, István (org). Brasil: Formação do Estado e da Nação. São Paulo: Hucitec-FapespEd. Unijui, 2003. p. 258-260.
Uma vez mais, o silêncio em relação à escravidão e ao tráfico negreiro foi estrategicamente empregado no texto constitucional, caracterizando 0 que Alencastro chamou de "compromisso para o futuro", onde "o Império do Brasil retoma e reconstrói a escravidão no quadro do direito moderno, dentro de um país independente, projetando-a sobre a contemporaneidade" 29.

A reafirmação da escravidão e do comércio transatlântico de escravos permitiu que a Constituição brasileira distinguisse aqueles que faziam parte do pacto, diferenciando direitos civis dos direitos políticos. ${ }^{30}$ Eram considerados cidadãos brasileiros todos os homens livres e os escravos nascidos no Brasil que obtivessem a alforria. No entanto, os cidadãos passiveis de serem eleitos deveriam fazer parte do Corte censitário definido, além de terem nascido ingênuos. Aos libertos brasileiros estava afiançado o direito de votarem, contanto que obedecessem o critério de renda. ${ }^{31}$

Enquanto vigorou o tráfico negreiro, a possibilidade dos libertos nascidos no Brasil tornarem-se cidadãos, mesmo não gozando plenamente dos direitos políticos, aliado ao significativo número de alforrias do país, foram estratagemas eficazes na manutenção da instituição escravista. Essa tática potencializou as ações individuais dos cativos como forma mais eficaz na luta pela obtenção da liberdade, em detrimento de possíveis levantes em massa. ${ }^{32}$ Dessa feita, não só o provimento de mão-de-obra continuava garantido, pois os escravos que adquirissem sua liberdade seriam substituídos por africanos novos, como o receio de sublevações cativas (que fizeram parte do horizonte das discussões liberais) ficava mais distante.

Embora não incorporados na Constituição, os libertos africanos viam, nas letras da lei, o direito à cidadania em aberto para seus filhos. A aceitação direta e indireta do legado escravista demonstra quão inclusiva era a Constituição do Brasil. Mais do que isso. Sugere como que heranças de um passado colonial escravista foram reelaboradas na construção de um novo pais. A equação entre grande número de cativos, volumoso tráfico de escravos africanos e alto indice de alforrias foram sancionadas em 1824, assegurando a perpetuação de práticas que haviam viabilizado a estabilidade do sistema escravista na América portuguesa.

Sendo assim, o governo do escravo continuava a ser responsabilidade do proprietário, que agora tinha esse direito garantido por meio da defesa constitucional da propriedade (artigo 179). Ao analisar a ordem nacional e o governo dos escravos, Marquese afirmou que os senhores faziam questão de exercer sua soberania doméstica, ficando a cargo do Estado auxiliar no controle dos cativos no espaço externo às casas. ${ }^{33}$ No que tange à escravidão urbana, esse espaço externo era deveras amplo e diversificado. Justamente por isso, nesses locais, o governo dos escravos era dividido entre proprietários e Estado, cabendo ao último entrar em ação quando o controle senhorial não fosse suficiente para garantir o bem público. No entanto, os dados trabalhados até o presente momento demonstram que, grosso modo, questões relacionadas à moradia escrava mantiveram-se sob a alçada do proprietário, pois era ele o responsável direto pelos elementos básicos da vida escrava - mesmo que tal responsabilidade significasse certo desleixo, ou se apresentasse como boa oportunidade para o cativo exercer sua autonomia.

Se o Estado brasileiro optou em manter muitas leis e práticas que regiam o sistema escravista como um todo, no caso urbano não foi diferente. Agora como sede do Império do Brasil, o Rio de Janeiro manteve sua dependência em relação ao trabalho escravo na execução das mais variadas tarefas. A malha urbana da cidade continuava se desenvolvendo desde 1808, levando 
34

FLORENTINO, Manolo. Em Costas Negras: uma história do tráfico de escravos entre a África e o Rio de Janeiro. São Paulo: Cia. das Letras, 1997. p. 51.

\section{5}

Cf. HOLlOWAY, Thomas. Policia no Rio de Janeiro. Repressão e resistência numa cidade do século XIX. Rio de Janeiro: Fundação Getúlio Vargas Editora, 1997. p. 57-58.

\section{6}

A organização desse volume, produzido sob a égide de um Estado independente, demonstra uma preocupação a mais das autoridades responáveis: passou a ser importante saber onde os delitos ocorrerriam, bem como quais os oficiais de polícia realizaram as prisões.

37

Arquivo Nacional. Relação de presos feita pela polícia, 1810-1821. Códice 403, vol. 3

38

Arquivo Nacional. "Termos de Bem viver". Coleção Policia da Corte. Códice 410 - vol.2

39

Ibidem, p. 274

\section{0}

Ibidem, p. 275.

41

Não foi encontrada nenhuma documentação complementar que esclarecesse se os termos eram feitos apenas pela vontade dos senhores em garantir um negócio, ou se havia algum tipo de imposição do Estado. Contudo, o estudo de outras fontes documentais, como as posturas e pedidos de licença para escravos ao ganho, sugere que a primeira hipótese é mais plausivel, já que o proprietário do escravo era quem mais corria risco nessa negociata. à criação, na década de 1820, da freguesia de Sacramento. 0 volume do tráfico, que já tinha aumentado com a transferência da Corte joanina, cresceu ainda mais: em 1822 cerca de 23.280 cativos desembarcaram no porto carioca, ultrapassando o número de $47.000 \mathrm{em} 1826 .{ }^{34}$

Sob a égide de um Estado independente que se formava, a polícia passou a controlar com maior assiduidade a movimentação escrava nas ruas do Rio. Feito Intendente em janeiro de 1825, Francisco Alberto Teixeira Aragão decretou diversas normas que pretendiam delimitar o horário no qual os cativos poderiam circular pela cidade, além de proibir a entrada deles em armazéns, tavernas e botequins. Também foi preocupação da Intendência de Polícia assegurar que interesses pessoais não interferissem na manutenção da ordem social, diminuindo com isso a violência arbitrária que caracterizou a prisão de escravos durante o periodo joanino. ${ }^{35}$

0 terceiro volume do códice 403 - onde se encontram os registros das prisões feitas entre 1825-1826 - é um exemplo desse duplo movimento das autoridades policiais. Junto com o menor número de ocorrência de escravos detidos e de certa reorganização no registro dos locais e datas das detenções ${ }^{36}$, também se observa a manutenção do mesmo padrão dos delitos cometidos por cativos no periodo joanino. Brigas nas ruas, vadiagens, capoeiras, pequenos furtos e, sobretudo, fugas continuaram a ser os principais motivos para a reclusão escrava. ${ }^{37}$ Por isso, as situações referentes à prática do morar sobre si continuam difíceis de serem encontradas e analisadas. As condições materiais da vida escrava permanenceram circunscritas à esfera privada das relações travadas entre senhores e cativos.

Mas existiu uma relevante preocupação estatal em melhor conhecer os súditos do Império brasileiro. Nesses mesmo dois anos, encontram-se no códice 410 os termos de abonação ou termos de fiança, igualmente produzidos pela policia. ${ }^{38}$ Assim como os termos de bem viver, o poder público permitia, pela letra do documento, que senhores alugassem ou "emprestassem" seus cativos para terceiros, prática comum em toda a sociedade escravista brasileira - tanto no campo, como na cidade. Ou seja, tratava-se de um acordo firmado entre dois homens livres (ou libertos) perante a Intendência, no qual o proprietário permitia que outrem usufruisse o trabalho de seu escravo, provavelmente em troca de algum tipo de remuneração.

Em primeiro de fevereiro de 1825 assinou:

Termo de fiança (...) Antonio José Moreira morador na Rua do Sacramento, em que abona Manuel Joaquim Martim para seu escravo mascatear na Vila de Marica. ${ }^{39}$

Dois dias depois, José Manoel Ferreiro Salgado, morador da Rua da Quitanda, abonou Francisco Ignácio Sebastião da Silva, para seus escravos mascatearem pela cidade, freguesia de Inhaúma (que na época fazia parte da zona rural da província do Rio de Janeiro), e terra firme até o município de Itaboraí. 40

Esses dois termos exemplificam que o aluguel de escravos que mascateavam - ou seja, faziam comércio - era relativamente simples: bastava o nome e o endereço do senhor, o nome do locatário e os locais em que os escravos iriam trabalhar. A ausência de menção a qualquer caracteristica do escravo (nome, idade, possiveis sinais) reafirma que se tratava de um acordo entre dois cidadãos sacramentado pelo poder público. ${ }^{41}$

Interessante notar que esses termos não apenas mostram as nuances do escravismo urbano (escravos que trabalhavam no comércio para 
42

Cf. FLORY, Thomas. El Juez de Paz y el Jurado em el Brasil Imperial, 1808-1871. Control social y estabilidad política em el nuevo Estado. México: Fundo de Cultura Econômica, 1986. p. 86.
43

Ibidem, p. 95-97. senhores que não eram seus proprietários), como também as possíveis complexidades dos arranjos escravos de moradia. Explicando: em todos os casos de abonação lidos, o senhor permitiu que seu escravo vivesse com outra pessoa (um proprietário em potencial), pois, provavelmente, iria receber alguma compensação em troca. Dessa forma, o escravo saía da casa de seu proprietário para viver com a pessoa que recebeu a abonação.

A maior parte dos termos de abonação se remete ao mascate cuja atividade consiste na venda ambulante de produtos. Isso sugere que o cativo ficaria sem pouso certo, dormindo aqui e ali nas vilas por onde passasse. E o mais intrigante é que essa instabilidade do morar escravo não aparecia como um problema para o cativo, para o abonado, para o senhor, e muito menos para a Intendência Geral de Polícia, que podia entender essa prática como excelente oportunidade para a fuga escrava.

A leitura dos termos de abonação permite entender que o Estado - representado pela Intendência e seus funcionários - não se preocupou em controlar, até meados da década de 1820, os locais de moradia dos cativos, pois essa função cabia ao seu senhor - o único responsável real pelo escravo, tanto que era seu nome e endereço que constavam nos termos. Seu papel era apenas garantir o controle, o que, nesse caso, ocorria por meio da própria redação dos termos de abonação.

No âmbito nacional, o Estado brasileiro tomou algumas medidas com o intuito de administrar e manter a ordem. A partir de 1826, quando as atividades parlamentares foram reiniciadas, boa parte dos deputados e senadores que exerciam o poder legislativo era partidária de um projeto de Estado nacional que pregasse maior autonomia das províncias e, consequentemente, a descentralização do poder. Em outubro de 1827, conforme previsto na Constituição, foi criado o cargo de Juiz de Paz, que passou a exercer as funções que antes cabiam aos juizes ordinários, juizes de vintena e ao almotacéo. 42 Diferentemente do que ocorrera no período colonial, esses magistrados seriam eleitos pelos cidadãos brasileiros e responderiam sobre os assuntos menores de cunho judicial de sua paróquia, inclusive aqueles que diziam respeito à escravidão. De maneira geral, tal medida deixava parte do poder judiciário do Brasil relativamente autônomo, tendo em vista que, a partir de então, esses juizes não seriam mais nomeados pelo monarca.

A criação desse cargo, que não se enquadrava na hierarquia judicial vigente, teve fortes repercussões. Por um lado, obteve apoio de muitos jornalistas, já que era uma forma de controlar o Imperador e da sociedade civil ficar mais próxima do poder. Por outro, foi desaprovada por políticos mais moderados que defendiam a centralidade do poder no Rio de Janeiro. Plataforma dos liberais reformistas, o juiz de paz era uma das peças que compunham esse projeto de Estado que, como se verá mais adiante, não vingou. De todo modo, tal cargo foi fundamental para o andamento e conhecimento da vida prática do pais, já que dentre suas obrigações estava a promoção de conciliações entre partes envolvidas em potenciais litígios, em brigas domésticas, danos causados por escravos, aplicação de posturas municipais, destruição e prevenção de quilombos, etc. Segundo Flory, os Juizes de Paz eram verdadeiros pacificadores sociais da comunidade, uma espécie de "autoridades de bairro". 43 Até 1830, esses magistrados ocuparam posição de destaque na administração nacional, embora sua atuação tenha variado nas diferentes localidades brasileiras, realizando funções que antes ficavam sob a alçada policial - instituição que agora estava submetida aos juizes. 
44

Cf. HOLLOWAY, Thomas. Polícia no Rio de Janeiro. Repressão e resistência numa cidade do século XIX. Rio de Janeiro: Fundação Getúlio Vargas Editora, 1997. p. 67-70.

\section{5}

ROSSATO, Jupiracy A . R. Sob os Olhos da Lei: o escravo urbano na legislação municipal da cidade do Rio de Janeiro (1830-1838). 2002. 152f. Dissertação (Mestrado em História Social). Universidade Federal Fluminense, Niterói, 2002.

46

Ibidem, p. 145

lbidem.

Acompanhando as medidas tomadas pelos reformadores liberais, em 1830 foi elaborado o Código Criminal, que definia claramente os crimes e prescrevia a pena para cada um deles. Embora fizesse referencias explícitas à escravidão, o documento não trouxe um conjunto de leis específicas para a escravidão. Os cativos criminosos se enquadravam nos artigos gerais. ${ }^{44}$ Data desse período a recomposição dos poderes das Câmaras Municipais, sobretudo a do Rio de Janeiro que, no período joanino havia ficado submetida à Intendência de Polícia.

No caso específico da Corte imperial, junto com os juízes de paz e o Código Criminal, foi elaborado um Código de Posturas, também em 1830, muito elucidativo da coerência com a qual o Estado governado por liberais reformadores encarou questões relacionadas à moradia escrava e ao cativeiro de forma geral. 0 recente estudo de Jupiracy Rossato 45 é esclarecedor sobre esse ponto. Ao analisar o escravo urbano na legislação municipal do Rio de Janeiro, Rossato percebeu um relativo silêncio das atas e posturas municipais sobre o assunto, o que a fez concluir que, apesar da Câmara dos Vereadores do Rio de Janeiro - responsável pela produção das leis municipais - estar a par dos problemas oriundos da escravidão urbana, soube acatar os limites da sua interferência na dinâmica do sistema, respeitando o direito privado de propriedade que cabia aos senhores. ${ }^{46}$ Nesse sentido, a autora acrescentou um dado fundamental à pesquisa de Leila Algranti: a escravidão urbana foi marcada não apenas pela ausência do feitor, mas esteve em comum acordo com os interesses dos sujeitos que pensaram, construíram e executaram o projeto do Estado Nacional Brasileiro - em sua maioria, proprietários de escravos.

0 silêncio das leis municipais sobre escravidão - que parecem seguir a mesma linha da Carta Constitucional de 1824 - é apenas aparente. A ação escrava esteve presente nas entrelinhas dos textos legais, mostrando seu peso nas práticas cotidianas. Isso fica mais evidente ao se analisar, juntamente com as leis gerais sobre o escravismo, as posturas municipais e os diferentes acordos, com caráter legal, produzidos a fim de melhor administrar a escravidão.

As posturas municipais eram leis que tinham vigor apenas no município em que eram elaboradas e, comumente, tinham validade de um ano. Os responsáveis pela elaboração das posturas eram os vereadores da Câmara Municipal que, partindo da preocupação em criar e manter uma cidade ordenada e das queixas dos cidadãos que chegavam até eles, debatiam e redigiam os códigos que iriam reger o espaço urbano.

Porém, diferentemente do que ocorria com os projetos de postura das demais cidades do Brasil, que deveriam ser sancionados pela Assembléia Provincial, as medidas elaboradas pela Câmara Municipal do Rio de Janeiro passavam pelo crivo do Ministério do Império e da Assembléia Geral (constituída da Câmara dos Deputados e o Senado do Império do Brasil), instâncias máximas do poder legislativo do país. ${ }^{47}$ Mais uma vez a importância do Rio de Janeiro como centro decisório fica nítida.

0 primeiro código de posturas do Rio de Janeiro foi aprovado em quatro de outubro de 1830, ainda no Primeiro Reinado, e contou, para sua elaboração, além da Comissão de Posturas formada por vereadores, com a participação (nas discussões que antecederam a elaboração do texto final) de cidadãos comuns, médicos, fiscais de freguesias, juizes de paz e chefes de polícia. ${ }^{48} 0$ objetivo fundante desse conjunto de leis era a busca da "civilização". 
49

FLORENTINO, Manolo. Em Costas Negras. Uma história do tráfico de escravos entre a África e o Rio de Janeiro. São Paulo: Cia. das Letras, 1997. p.51.

50

Ibidem, p. 78-82.

51

Atualmente, muito se tem pesquisado sobre as relações e redes de solidariedade dos escravos mina, responsáveis por boa parte da atividade do ganho no Rio de Janeiro a partir da década de 1840. Cf. FARIAS, Juliana .B; SOARES, Carlos Eugenio Libano; GOMES, Flávio S. No Labirinto das Nações. Africanos e identidades no Rio de Janeiro, século XIX. Rio de Janeiro: Arquivo Nacional, 2005, capitulos 3,5 e 6. FLORENTINO, Manolo. Sobre minas, crioulos e a liberdade costumeira no Rio de janeiro, 1789-1817. In:______ (org.) Tráfico, Cativeiro e Liberdade. Rio de Janeiro, séculos XVII-XIX. Rio de Janeiro: Civilização Brasileira, 2005, p. 231-265. Todavia, é importante ressaltar que, até a década de 1830 , os escravos oriundos da África Central representavam a maior parte dos cativos da cidade. Dessa forma faz-se necessário compreender mais detalhadamente as heranças que esses homens e mulheres empregavam no cotidiano urbano. Um estudo que parte dessa abordagem é: SOUZA, Marina de Mello e. Reis Negros no Brasil Escravista. História da Festa de Coroação de rei Congo. Belo Horizonte: Editora UFMG, 2002.

52

Cf. RODRIGUES, Jaime. O Infame Comércio. Propostas e experiências no final do tráfico de Africano para o Brasil (1800-1850). Campinas: Editora da UNICAMP, 2000. p. 101-103.
As Posturas foram divididas em duas seções, cada qual subdividida em títulos, que por sua vez abarcavam certo número de artigos. A simples leitura desses títulos permite observar que, grosso modo, a grande preocupação das posturas era promover o bem público por meio da manutenção da ordem e do combate a qualquer ação que pudesse causar algum distúrbio à cidade. Dentre os diferentes assuntos abordados, nota-se a presença, um tanto secundária, da escravidão.

A partir de 1831 verificam-se mudanças substanciais da postura estatal frente à questão da escravidão. A abdicação de D. Pedro I e a abolição legal do tráfico transatlântico de escravos deram novos rumos para a formação do Império, na medida em que trouxeram à tona transformações no poder executivo e moderador do pais, assim como mudanças radicais na forma de obtenção da principal mão-de-obra brasileira. 0 tráfico negreiro foi colocado em xeque, exigindo, uma vez mais, que os políticos brasileiros repensassem o pais que estavam formando. Importante ressaltar que o fim do comércio transatlântico de escravos já fazia parte do horizonte daqueles que pensavam e governavam o Brasil. Apesar do silêncio estratégico da Carta Constitucional sobre a escravidão e o tráfico negreiro, as pressões inglesas para o fim gradual da primeira e a abolição imediata do segundo foram pauta de muitas reuniões parlamentares.

Os dados sobre o tráfico de africanos escravizados demonstram não só a freqüente quebra dos tratados firmados entre a Corte joanina e o governo inglês, como o incremento desse comércio, sobretudo nas possessões africanas em que ele era permitido. Entre 1810 e 1821, o número de africanos desembarcados no Rio de Janeiro girou em torno dos 18 a 20 mil, com exceção de 1815, ano em que entraram pouco mais de 13 mil cativos no porto carioca. ${ }^{49}$ Nos primeiros trinta anos do século XIX, houve um significativo aumento de negreiros oriundos dos portos da África Central Atlântica e da África Oriental (principalmente depois de 1811) e uma diminuição dos navios que saíam da África Ocidental, justamente a parte do continente com a qual portugueses e brasileiros estavam proibidos de negociar. 50 Não por acaso, até a década de 1830, os africanos congo e angola (África Central) povoaram as ruas do Rio de Janeiro e foram encontrados, diversas vezes, em situações de moradia autônoma. ${ }^{51}$

Contudo, a crescente pressão da Inglaterra, que colocou o final do tráfico como condição para o reconhecimento da independência do país, aumentava proporcionalmente ao número de desembarques de africanos na Corte. Junto com isso, a ascensão de uma política mais liberal no país e a disseminação de certos ideais antiescravistas fizeram com que, em 1826, fosse assinado outro tratado entre as duas nações, no qual o Brasil se comprometia a abolir, em três anos, o comércio transatlântico de escravos. ${ }^{52} \mathrm{~A}$ falta de consenso dentro do próprio Congresso sobre o final do tráfico negreiro adiou a data prevista para a execução do tratado, indicada para o final de 1830. Em novembro de 1831, num ato de afirmação do Parlamento sobre o poder Executivo, era abolido o comércio transatlântico de africanos.

A proibição, em tese, colocava em risco a existência da escravidão no Brasil, na medida em que bloqueava a principal fonte fornecedora de cativos desde o século XVI. Mas esta era uma projeção para o longo prazo. A despeito da proibição, o Estado brasileiro continuava escravista, só que agora diante do problema de como fazer a reposição dessa mão-de-obra. Caso seja permitido a elaboração de um raciocínio conjectural, a medida 
53

Cf. KARASCH, Mary. A Vida Escrava no Rio de Janeiro (1808-1850). São Paulo: Cia. Das Letras, 2000, capítulo 11. Trabalhos mais recentes têm explorado com maior cuidado a questão das alforrias no Rio de Janeiro, inclusive inferindo alguns padrões nessa prática deveras difundida na sociedade brasileira escravista. Cf. FLORENTINO M. (org.) Tráfico, Cativeiro e Liberdade. Rio de Janeiro, séculos XVII-XIX. Rio de Janeiro: Civilização Brasileira, 2005, parte 3. p. 285-417.

54

MATTOS, Ilmar R. O Tempo Saquarema: a formação do Estado Imperial. São Paulo: Hucitec, 1990.

\section{5}

Cf. PARRON, Tâmis P A Politica do Tráfico Negreiro no Império do Brasil, 1826 a 1850. Relatório Final FAPESP de Iniciação Científica. Faculdade de Filosofia, Letras e Ciências Humanas. Universidade de São Paulo, 2006, p. 62-66. Uma das idéias centrais trabalhadas por Tâmis Parron reside na diferenciação que ele estabeleceu entre as duas fases da ilegalidade do tráfico. A primeira chamada fase residual, compreende os anos de 1831 a 1835, quando o contrabando teve números baixos e não contou com a anuência do parlamento. Já na fase sistêmica, 1836 a 1850, a ilegalidade desse comércio contou com o suporte de parlamentares engajados no que ele chamou de uma política da escravidão. traria implicações para diversos aspectos da instituição no Brasil, podendo, inclusive, comprometer o exercício de práticas que permitiam maior autonomia escrava; dentre eles, a possibilidade do cativo urbano morar sobre si. Desse modo, o fim do tráfico incidiria diretamente nas relações estabelecidas entre proprietários e seus escravos, fato que poderia alterar o quadro dos arranjos escravos de moradia vistos até aqui.

Prosseguem as conjecturas. Desde início do periodo colonial, a mãode-obra cativa era reproduzida, fundamentalmente, por meio do comércio de africanos. Essa prática fez com que os senhores pouco se preocupassem com a reposição de seus trabalhadores. A lucratividade desse negócio era tamanha que gerou práticas nas quais era mais vantajoso o esgotamento da força cativa por meio da total otimização do trabalho, do que o investimento na reprodução natural da escravaria, como ocorreu nos Estados Unidos. A interrupção abrupta dessa forma de obter cativos resultaria na escassez da mãode-obra. Conseqüentemente, ocorreria uma valorização do segmento escravo no mercado, o que levaria os senhores a, no mínimo, serem mais cuidadosos com seus cativos, mesmo que para isso fosse necessário aumentar ainda mais a violência inerente às relações escravistas.

No que tange à moradia escrava no Rio de Janeiro, a permissão velada para o cativo morar sobre si sofreria grande diminuição, fato que implicaria o aumento de fuga e crimes escravos, e no uso da casa senhorial como principal, quando não o único, espaço de moradia. Uma coisa era um proprietário correr o risco de permitir que seu cativo morasse sobre si em uma sociedade na qual o valor do escravo era baixo, porque era um bem facilmente reposto. Outra, bem diferente, seria a manutenção de tal prática numa sociedade que não mais contaria com o fomento constante de novos escravos.

E mais, o provável aumento de preço do cativo poderia resultar em uma exploração ainda maior dessa mão-de-obra sem a contrapartida da possibilidade da compra ou concessão da alforria, levando em consideração a sua valorização. Mesmo que a liberdade tenha sido adquirida por um número relativamente pequeno de escravos ${ }^{53}$, o vislumbre dela fez parte do imaginário de todo e qualquer cativo, especialmente daqueles que trabaIhavam e moravam nos grandes centros urbanos. Dito de outra forma, o fim do tráfico colocaria em risco a permanência da resistência escrava mais difundida no Rio, a resistência individual, e, ao fazer isso, ampliaria a probabilidade de articulações escravas na luta contra a instituição.

Como se sabe, no entanto, nada disso se verificou até 1850. A partir de 1835, a disputa entre os dois principais projetos politicos para a formação do Estado nacional brasileiro acabou resultando na vitória dos parlamentares conservadores, também conhecidos como saquaremas. ${ }^{54}$ Dentre as inúmeras medidas adotadas por esses políticos, que em linhas gerias pretendiam criar um Estado forte, centralizado, escravista e que beneficiasse os grandes produtores rurais, no ano de 1836 o tráfico negreiro foi reaberto sistemicamente na ilegalidade, recebendo, a partir do ano seguinte, 0 aval do parlamento. ${ }^{55}$ Mais uma vez, as ações estatais expressaram a união entre interesses políticos e econômicos das elites brasileiras.

A reabertura sistêmica do tráfico ilegal por quase quinze anos resultou, ao mesmo tempo, no mais volumoso transporte de africanos já vistos para o Brasil - que fez do Rio de Janeiro a maior cidade escravista das Américas -, bem como na consolidação do projeto de formação do Estado nacional brasileiro nos moldes propostos pelos saquaremas, projeto esse que dava lugar de destaque à Corte imperial e à escravidão. 
A partir de então é possivel vislumbrar maior atenção das autoridades no que diz respeito ao controle sobre os escravos. Em 1838, outro Código de Posturas foi aprovado pela Câmara Municipal do Rio de Janeiro no qual os títulos dedicados aos escravos foram mais numerosos do que no Código anterior. Todavia, não houve nenhuma menção à prática do morar sobre si.

Na realidade, até a abolição da escravidão a prática do morar sobre si foi determinada pelos acordos privados entre os escravos e seus proprietários tendo sido tolerada pelos órgãos estatais. 0 caso do escravo Amiceto, que inicia esse trabalho, é um exemplo disso. 0 morar sobre si poderia trazer certas tensões; porém, a conjunção entre o poder senhorial (determinante privado) e o jogo de forças na esfera do Estado que perdurou durante a vigência do tráfico (determinante público) foi de tal ordem que impediu uma possivel proibição dessa prática. Durante a primeira metade do oitocentos, não houve nenhuma proibição legal sobre qualquer aspecto da moradia escrava, entendida strito sensu. Bondade senhorial? Frouxidão estatal? Não.

Ninguém melhor do que o proprietário sabia as conseqüências que o impedimento de uma prática disseminada poderia trazer. Seria o mesmo que interditar a possibilidade da alforria, largamente difundida no espaço urbano, ou então retirar os domingos e feriados dos cativos rurais. Foi por meio desse jogo de negociações que a escravidão se manteve durante tantos anos. E foi justamente por isso que a análise sobre o morar escravo se deparou com o silêncio constante do Estado brasileiro que se formava; não cabia a ele zelar pelas condições matérias da vida escrava.

Recebido para publicação em julho de 2007

Aprovado em setembro de 2007 